[Chem. Pharm. Bull.

35( 6 )2459-2464(1987)]

\title{
Antitumor Mechanisms of Orally Administered Shiitake Fruit Bodies
}

\author{
Hiroaki Nanba* and Hisatora Kuroda \\ Laboratory of Microbiology, Kobe Women's College of Pharmacy, \\ Motoyama, Higashinada, Kobe 658, Japan
}

(Received August 30, 1986)

\begin{abstract}
When tumor-bearing mice were given diet containing fruit bodies of shiitake (L-feed), the tumor growth was apparently inhibited. To elucidate the mechanisms of this action, the effects of the $\mathrm{L}$-feed on the production superoxide anion (SOA) by macrophages and the cytotoxicity of natural killer T cells were studied. When MM-46 carcinoma-bearing $\mathrm{C} 3 \mathrm{H}$ mice were maintained on $\mathrm{L}-\mathrm{feed}$ (containing $20 \%$ shiitake powder), SOA production by macrophages was increased about 2.0 to 2.3 times. Furthermore, the cytotoxic activities of natural killer cells and killer T cells were increased 1.9 times and 1.4 times, compared with their counterparts from normal $\mathrm{C} 3 \mathrm{H}$ mice fed on shiitake-free diet. These results suggest that shiitake powder given orally activates various effector cells to attack tumor cells. It appears to potentiate cellular functions and at the same time to prevent a decrease of immune function of the tumor-bearing host.
\end{abstract}

Keywords - shiitake; antitumor activity; macrophage; natural killer cell; superoxide anion; cytotoxic T cell

Dietary administration of shiitake (L. edodes) fruit bodies was shown previously to inhibit the growth of both allogeneic and syngeneic tumors in mice. ${ }^{1)}$ This antitumor activity was suggested to depend on immunological effector cells including macrophages. To delineate the mechanism further, the present study was designed. According to Chihara et al., ${ }^{2)}$ lentinan, a glucan consisting of a $\beta$-1,3-glucopyranoside chain with 1,6-glucopyranoside branches, extracted from the fruit bodies of shiitake acts as an immunostimulant to develop tumor immunity against allogeneic and some syngeneic tumors. It is widely accepted that activated macrophages, cytotoxic $\mathrm{T}$ cells, natural killer cells, and killer $\mathrm{T}$ cells usually play important roles in tumor immunity. ${ }^{2,3)}$ Lentinan has been reported to enhance the activity of these immune systems when administered intraperitoneally, subcutaneously, or intravenously. In order to study the mechanisms of antitumor action following oral administration, mice were maintained on feed containing powdered shiitake fruit bodies (L-feed) and the effects on the activities of macrophages and cytotoxic $T$ cells were examined. The results are described in this paper.

\section{Materials and Methods}

Feeds - The experimental diet containing $20 \%$ powdered shiitake fruit bodies, which were provided by the Mushroom Research Institute of Japan (Kiryu, Gumma), were prepared as described previously (L-feed). ${ }^{1}$ Mice receiving shiitake-free diet (normal feed) served as controls.

Animals - Male mice of the ICR strain (5 to 6 weeks old), of the C3H strain (6 weeks old), and of the $\mathrm{CDF}_{1}$ strain (5 to 6 weeks old) were obtained from Charles River Japan, and were maintained on commercial mouse chow for 1 week then used for the experiment.

Collection of Macrophages - The $\mathrm{CDF}_{1}$ and $\mathrm{C} 3 \mathrm{H}$ mice were maintained on either normal feed or $\mathrm{L}$-feed during the periods indicated, and their peritoneal cavities were rinsed with Hanks' solution. The solution was centrifuged at $1200 \mathrm{rpm}$ for $10 \mathrm{~min}$ to collect cells. The cell pellet was suspended in RPMI-1640 medium, and the suspension was adjusted to $1 \times 10^{6}$ cells. Then $1.5 \mathrm{ml}$ portions of this suspension were seeded onto a plastic plate, and the plate was incubated at $37^{\circ} \mathrm{C}$ for $2 \mathrm{~h}$ in an atmosphere of $5 \% \mathrm{CO}_{2}$ in air saturated with water vapor. Macrophages adhered to 
the plastic plate. Non-adherent cells were removed by rinsing the plate 3 times with Hanks' solution.

Preparation of |Fluorescen-Listeria_Listeria were inoculated into $10 \mathrm{ml}$ of nutrient broth medium containing $0.1 \mathrm{ml}$ of fluorescen solution and cultured at $37^{\circ} \mathrm{C}$ for $24-36 \mathrm{~h}$. The culture was centrifuged at $1200 \mathrm{rpm}$ for $10 \mathrm{~min}$. The bacterial sediment was washed 3 times with the same medium and heated at $100^{\circ} \mathrm{C}$ for $10 \mathrm{~min}$, then suspended in saline for the experiment. The amount of Listeria in phagosomes of macrophages was measured by flow cytometry (Ortho Spectrum III).

Determination of Superoxide Anion (SOA) _-Male mice of the ICR strain (5 to 6 weeks old), of the C3H strain (6 to 7 weeks old), and of the $\mathrm{CDF}_{1}$ strain (6 to 7 weeks old) were maintained on the normal feed or the L-feed. Peritoneal macrophages were obtained from the mice as described above, and the amount of released SOA was measured by the method of Ito et al ${ }^{4)} \mathrm{A} 1.5 \mathrm{ml}$ aliquot of phosphate-buffered saline (PBS) containing $10 \mathrm{~mm}$ glucose, $80 \mu \mathrm{M}$ ferricytochrome $\mathrm{c}$, and $0.2 \mathrm{mg} / \mathrm{ml}$ opsonized zymosan was added to macrophages adhering to a plate. The mixture was incubated for $90 \mathrm{~min}$ and centrifuged at $3000 \mathrm{rpm}$ for $5 \mathrm{~min}$. The supernatant was transferred into a test tube chilled with ice to stop the reaction and the absorbance was measured at $550 \mathrm{~nm}$. A $1 \mathrm{ml}$ aliquot of $0.5 \%$ sodium dodecyl sulfate (SDS) was added to the cells remaining at the bottom of the plate. After 5 min, the number of cells in the solution was determined by measuring protein content according to Lowry's method. ${ }^{5)}$ The quantity (nmol) of ferricytochrome $\mathrm{c}$ was obtained from the absorbance at $550 \mathrm{~nm}$, according to the formula $\Delta E 550 \mathrm{~nm}=2.1 \times 10^{4} \mathrm{M}^{-1}$, and the amount of SOA per unit protein was calculated. For opsonization of zymosan, zymosan A was adjusted with PBS to $50 \mathrm{mg} / \mathrm{ml}$, boiled for $1 \mathrm{~h}$, washed 3 times, and resuspended in PBS at $50 \mathrm{mg} / \mathrm{ml}$. Four volumes of human serum and one volume of $50 \mathrm{mg} / \mathrm{ml}$ zymosan were incubated at $37^{\circ} \mathrm{C}$ for $30 \mathrm{~min}$ and after centrifugation, $10 \mathrm{mg}$ of opsonized zymosan was resuspended in $1 \mathrm{ml}$ of PBS.

Phagocytic Activity Assay-MM-46 carcinoma tumor cells, preliminarily cultured for $7 \mathrm{~d}$ in the peritoneal cavity of $\mathrm{C} 3 \mathrm{H}$ mice, were collected and washed with Hanks' solution by centrifugation ( $1200 \mathrm{rpm}, 5 \mathrm{~min})$, and $2 \times 10^{7}$ tumor cells were resuspended in $1 \mathrm{ml}$ of RPMI- 1640 medium containing $1.0 \mu \mathrm{Ci}(25 \mu \mathrm{l})$ of ${ }^{3} \mathrm{H}$-uridine. The suspension was cultured for $2 \mathrm{~h}$, then free ${ }^{3} \mathrm{H}$-uridine was rinsed away with about $500 \mathrm{ml}$ of Hanks' solution. ${ }^{6}$ The labeled tumor cells were submitted to phagocytic assay at an E/T ratio of 50:1 for $2 \mathrm{~h}$. After incubation, adherent macrophages were collected and dissolved in toluene. The radioactivity $(\mathrm{dpm})$ incorporated into macrophages was counted on a liquid scintillation counter (Aloka LSC-700). The presence of phagocytosed tumor cells in macrophages was detected by microscopy.

Preparation of Spleen Cell Suspension ${ }^{7}$ __ A male C3H mouse (6 to 7 weeks old) was killed by vertebral dislocation. The mouse was bled by cutting the femoral vein and the spleen was extirpated. After being washed with Eagle's minimum essential medium (MEM), the spleen was teased with scissors and passed through an 80 mesh stainless steel sieve. The cells were collected by centrifugation at $1200 \mathrm{rpm}$ for $10 \mathrm{~min}$, than $2 \mathrm{ml}$ of 10 -fold dilution of Eagle's MEM was added to lyse contaminating erythrocytes hypotonically for $10 \mathrm{~s}$. The cell suspension was immediately added to $2 \mathrm{ml}$ of Eagle's MEM (2-fold concentration). The suspension was centrifuged at $1200 \mathrm{rpm}$ for $10 \mathrm{~min}$, and the cells thus obtained were adjusted to $1 \times 10^{7}$ cells $/ \mathrm{ml}$ with RPMI-1640 medium. This was used as the whole spleen cell suspension. This suspension was placed in a Petri dish ( $5 \mathrm{~cm}$ in diameter) and incubated for $60 \mathrm{~min}$. Then, non-adherent cells were exclusively collected, adjusted to $1 \times 10^{7}$ cells $/ \mathrm{ml}$ with RPMI-1640 medium, and used as non-adherent spleen cells. In this experiment, the cytotoxic activity of NK was assayed at an E/T ratio of $50: 1$.

Elimination of $\mathbf{T}$ Cells $^{8}$ ___ A mixture of $1 \mathrm{ml}$ of non-adherent spleen cell suspension obtained from male $\mathrm{C} 3 \mathrm{H}$ mice (7 weeks) and $20 \mu \mathrm{l}$ of 5\% Thy-1.2 F7D5 monoclonal immunoglobulin M antibody (Serotec Ltd. England) was incubated for $30 \mathrm{~min}$, then the cells were washed once with RPMI-1640 medium. After that, $1 \mathrm{ml}$ of RPMI-1640 medium with fetal bovine serum containing $5 \%$ guinea pig complement was added, and the whole was further incubated for $30 \mathrm{~min}$. The cells that reacted with antibody were selectively destroyed. The remaining cells were sedimented by centrifugation at $1200 \mathrm{rpm}$ for $10 \mathrm{~min}$ and rinsed 3 times with RPMI-1640 medium. The cells were adjusted to $1 \times 10^{7}$ cells $/ \mathrm{ml}$.

Cytotoxicity A $1 \mathrm{ml}$ aliquot of the labeled target cell suspension $\left(2 \times 10^{5}\right.$ cells $\left./ \mathrm{ml}\right)$ was mixed with $1 \mathrm{ml}$ of the lymphocyte suspension $\left(1 \times 10^{7}\right.$ cells $\left./ \mathrm{ml}\right)$ and $0.5 \mathrm{ml}$ aliquots were incubated for $4 \mathrm{~h}$. Then, $0.4 \mathrm{ml}$ of reaction mixture was suction-filtered through a Millipore filter $(0.45 \mathrm{~nm}$ pore size, Millipore Co.). After being washed with $15 \mathrm{ml}$ of cold $5 \%$ trichloroacetic acid (TCA) solution, the filter was dried and mixed with $10 \mathrm{ml}$ of lipophilic scintillator. Radioactivity was measured with a scintillation counter. The cytotoxicity $\left(P_{0}^{\circ}\right)$ was calculated according to the following formula:

$$
P(\%)=\left(1-\frac{\mathrm{dpm} \text { with immunolymphoyctes-background dpm }}{\mathrm{dpm} \text { when target cells only were incubated-background dpm }}\right) \times 100
$$

\section{Results and Discussion}

In the previous paper, ${ }^{1)}$ we reported that the inhibitory effect of shiitake fruit bodies on the growth of tumors varied depending on the type of tumor-host system. MM-46 carcinoma 
in $\mathrm{C} 3 \mathrm{H}$ mouse showed about $80 \%$ tumor growth inhibition, whereas with IMC carcinoma in $\mathrm{CDF}_{1}$ mouse the inhibition was as low as about $20 \%$. Therefore, these two systems were chosen for this study. At $10 \mathrm{~d}$ after tumor implantation, peritoneal macrophages were collected and assayed for phagocytic activity towards fluorescen-labeled Listeria. As shown in Table I, the phagocytic activity of macrophages from tumor-bearing $\mathrm{C} 3 \mathrm{H}$ mice increased 2.3 times, when the hosts had been given L-feed. However, the activity was decreased when they had been maintained on normal feed. In the case of tumor-bearing $\mathrm{CDF}_{1}$ mice, the activity was increased about 1.8 times.

The phagocytic activity of macrophages against syngeneic tumor cells was examined. As shown in Fig. 1, macrophages from mice given normal feed showed no alteration of phagocytic activity against MM-46 tumor cells, regardless of duration of feeding. On the other hand, when mice were maintained on L-feed, the phagocytic ability was increased with duration of feeding. The number of tumor cells phagocytosed by macrophages reached about $18-25 \%$ of total tumor cells used.

The study was centered on the amount of SOA released by macrophage in phagocytosis, as one of the criteria of cytotoxicity of activated macrophages. As shown in Table II, macrophages obtained from ICR mice given L-feed for $15 \mathrm{~d}$ after implantation of Sarcoma-

TABLE I. Phagocytic Activities of Macrophages from $\mathrm{CDF}_{1}$ and $\mathrm{C} 3 \mathrm{H}$ Mice Given L-Feed or Normal Feed

\begin{tabular}{ccccc}
\hline \multicolumn{2}{c}{ Mice and tumor } & \multicolumn{1}{c}{ Feed } & No. of Listeria $^{a)}$ & Ratio \\
\hline \multirow{2}{*}{ C3H mice } & \multirow{2}{*}{ Non-bearing } & Normal feed & $17.1 \pm 2.2$ & 1.00 \\
& & L-Feed & $31.2 \pm 1.1^{c)}$ & 1.83 \\
& \multirow{2}{*}{ MM-46 bearing } & Normal feed & $12.6 \pm 1.3^{b)}$ & 0.74 \\
& & L-Feed & $39.3 \pm 1.1^{d)}$ & 2.31 \\
CDF $_{1}$ mice & \multirow{2}{*}{ Non-bearing } & Normal feed & $13.2 \pm 3.2$ & 1.00 \\
& \multirow{3}{*}{ IMC-bearing } & L-Feed & $15.5 \pm 0.8^{b)}$ & 1.17 \\
& & Normal feed & $8.2 \pm 0.5^{c}$ & 0.62 \\
& & L-Feed & $23.4 \pm 1.3^{c)}$ & 1.77 \\
\hline
\end{tabular}

a) No. of Listeria/cell (average of 200 cells). Significance of differences $(t$-test): $b) p<0.05, c) p<0.01$, d) $p<0.001$.

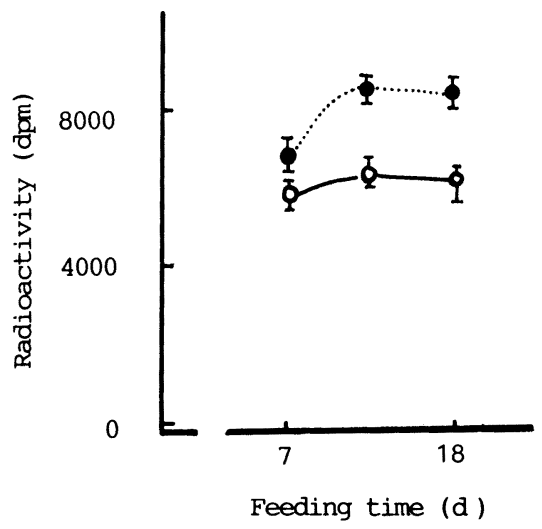

TABLE II. Release of SOA by L-Feed-Induced Macrophages from Tumor-Bearing Mice

\begin{tabular}{clcc}
\hline \hline Mice & \multicolumn{1}{c}{ Feed } & $\begin{array}{c}\text { SOA release } \\
(\mathrm{nmol} / \mathrm{mg} \text { protein })\end{array}$ & Ratio \\
\hline Normal ICR & $\begin{array}{l}\text { Normal feed } \\
\text { L-Feed }\end{array}$ & $12.40 \pm 0.83$ & 1.00 \\
& $13.65 \pm 1.13$ & 1.10 \\
Sarcoma-180 & Normal feed & $11.83 \pm 0.78^{a)}$ & 0.95 \\
bearing ICR & L-Feed & $25.86 \pm 1.06^{b)}$ & 2.08 \\
\hline
\end{tabular}

Significance of differences ( $t$-test): $a) p<0.05, b) p<0.01$.

Fig. 1. Phagocytic Activity of ${ }^{3} \mathrm{H}$-UridineLabeled MM-46 Carcinoma by Macrophages from C3H Mice Given L-Feed or Normal Feed 
TABLE III. Time Course of SOA Release by L-Feed-Induced Peritoneal Macrophage from IMC Tumor-Bearing Mice

\begin{tabular}{|c|c|c|c|c|c|c|c|}
\hline \multirow{3}{*}{ Mice and tumor } & \multirow{3}{*}{ Feed } & \multicolumn{6}{|c|}{ SOA release } \\
\hline & & \multicolumn{3}{|c|}{ After $10 \mathrm{~d}$} & \multicolumn{3}{|c|}{ After $20 \mathrm{~d}$} \\
\hline & & $\begin{array}{c}(\mathrm{nmol} / \mathrm{mg} \\
\text { protein) }\end{array}$ & \multicolumn{2}{|c|}{ (ratio) } & $\begin{array}{c}(\mathrm{nmol} / \mathrm{mg} \\
\text { protein) }\end{array}$ & \multicolumn{2}{|c|}{ (ratio) } \\
\hline \multirow[t]{2}{*}{ Normal $\mathrm{CDF}_{1}$} & Normal feed & $7.8 \pm 2.42$ & $(1.00)$ & & $4.8 \pm 1.83$ & $(1.00)$ & \\
\hline & L-Feed & $9.2 \pm 1.52^{a)}$ & $(1.18)$ & & $8.6 \pm 1.73^{a)}$ & $(1.79)$ & \\
\hline \multirow[t]{2}{*}{ IMC-bearing $\mathrm{CDF}_{1}$} & Normal feed & $6.2 \pm 3.11$ & $(0.79)$ & $(1.00)$ & $3.4 \pm 1.97$ & $(0.70)$ & $(1.00)$ \\
\hline & L-Feed & $8.3 \pm 1.11^{a)}$ & $(1.06)$ & $(1.34)$ & $6.6 \pm 1.95^{a)}$ & $(1.37)$ & (1.94) \\
\hline
\end{tabular}

Significance of differences ( $t$-test): $a) p<0.05$.

TABLE IV. Time Course of SOA Release by L-Feed-Induced Peritoneal Macrophages from MM-46 Tumor-Bearing Mice

\begin{tabular}{|c|c|c|c|c|c|c|c|}
\hline \multirow{3}{*}{ Mice and tumor } & \multirow{3}{*}{ Feed } & \multicolumn{6}{|c|}{ SOA release } \\
\hline & & \multicolumn{3}{|c|}{ After $9 \mathrm{~d}$} & \multicolumn{3}{|c|}{ After $18 \mathrm{~d}$} \\
\hline & & $\begin{array}{c}(\mathrm{nmol} / \mathrm{mg} \\
\text { protein) }\end{array}$ & \multicolumn{2}{|c|}{ (ratio) } & $\begin{array}{c}(\mathrm{nmol} / \mathrm{mg} \\
\text { protein) }\end{array}$ & \multicolumn{2}{|c|}{ (ratio) } \\
\hline Normal C3H & Normal feed & $26.9 \pm 0.87$ & $(1.00)$ & & $18.9 \pm 1.08$ & $(1.00)$ & \\
\hline & L-Feed & $25.3 \pm 0.79$ & $(0.94)$ & & $20.1 \pm 0.77$ & $(1.06)$ & \\
\hline \multirow[t]{2}{*}{$\mathrm{MM}-46$ bearing $\mathrm{C} 3 \mathrm{H}$} & Normal feed & $19.9 \pm 0.97$ & $(0.74)$ & $(1.00)$ & $9.5 \pm 1.43$ & $(0.50)$ & $(1.00)$ \\
\hline & L-Feed & $40.1 \pm 0.85^{a)}$ & $(1.49)$ & $(2.01)$ & $21.9 \pm 1.18^{a}$ & $(1.16)$ & $(2.31)$ \\
\hline
\end{tabular}

Significance of differences ( $t$-test): a) $p<0.05$.

180 tumor cells produced less SOA than those from their tumor-free counterparts. When the mice were given L-feed, macrophages obtained from tumor-bearing mice released twice as much SOA as those from normal mice.

The results on SOA production in macrophages obtained from syngeneic tumor-bearing mice are summarized in Tables III and IV. In the case of $\mathrm{CDF}_{1}$ mice given L-feed for 10 or $20 \mathrm{~d}$ after implantation of IMC-tumor cells, the SOA production was increased to $1.1-1.4$ times that of normal mice given normal feed. However, as shown in Table IV, in the case of $\mathrm{C} 3 \mathrm{H}$ mice (in which the inhibition of MM-46 tumor growth was greater), the amount of released SOA was increased about 2.0-2.3 times by L-feed for $9 \mathrm{~d}$. However, when the mice were given L-feed for $18 \mathrm{~d}$, the produced SOA was almost the same as that for normal mice given normal feed for $18 \mathrm{~d}$.

These results suggest that tumor growth inhibition by the shiitake fruit bodies is at least partly due to enhanced production of SOA by macrophages or prevention of deterioration of immuno-phagocytosis in the tumor-bearing state.

Next, the effects of shiitake powder on NK cells (nonspecifically injuring tumor cells), and cytotoxic $\mathrm{T}$ cells (Tc, specifically injuring antigen-presenting cells) were studied. First of all, NK cells; which are induced from pre-NK cells by IFN, were studied. Spleen cells were used as a cell group containing NK cells, and YAC-1 tumor cells were labeled with ${ }^{3} \mathrm{H}$-uridine as target cells. $\mathrm{C} 3 \mathrm{H}$ mice were given $\mathrm{L}$-feed for $8 \mathrm{~d}$, and non-adherent spleen cell suspension was prepared from the extirpated spleen. The cytotoxicity of this cell fraction against YAC-1 tumor cells was measured at an $\mathrm{E} / \mathrm{T}$ ratio of $50: 1$. As shown in Table $\mathrm{V}$, the NK cell activity 
TABLE V. Effects of L-Feed on NK Activity of Non-adherent Spleen Lymphocytes against YAC-1 Tumor Cells

\begin{tabular}{ccc}
\hline \multicolumn{1}{c}{ Feed } & $\begin{array}{c}\text { NK activity }(\%) \\
\text { (relative cytotoxicity) }\end{array}$ & Ratio \\
\hline Normal feed & $6.83 \pm 1.79$ & 1.00 \\
L-Feed & $12.84 \pm 0.88^{a)}$ & 1.88
\end{tabular}

Significance of difference ( $t$-test): $a) p<0.05$. E/T (NK cell $1 \times 10^{7}:$ YAC- 1 cell $2 \times 10^{5}$ ) ratio $=50: 1$.

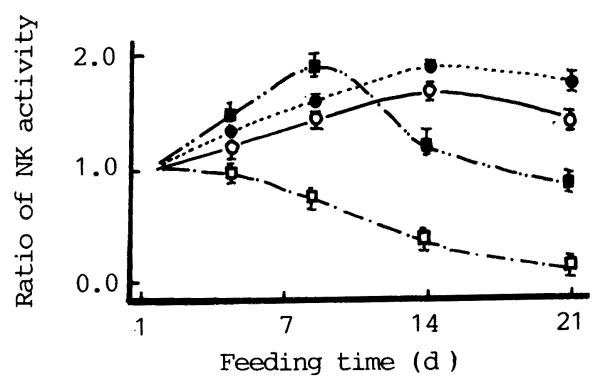

Fig. 2. Time Course of Activities of NK Cells from $\mathrm{C} 3 \mathrm{H}$ Mice Given L-Feed or Normal Feed $\mathrm{O}-\mathrm{O}$, normal $\mathrm{C} 3 \mathrm{H}$ (normal feed); $\bullet--\bullet$, normal C3H (L-feed); $\square---\square$, MM-46-bearing (normal feed); $-\mathbf{\square}$, MM-46-bearing (L-feed).

TABLE VI. Effects of L-Feed on the Development of Allogeneic Cytotoxic T-Lymphocytes

\begin{tabular}{clllc}
\hline \hline Feed & \multicolumn{1}{c}{ Treatment } & Cytolysis $(\%)$ & \multicolumn{2}{c}{ Ratio } \\
\hline \multirow{2}{*}{ Normal feed } & Non & $21.4 \pm 0.63$ & 1.00 & 1.00 \\
& Anti-Thyl.2+C' & $11.5 \pm 1.52$ & 0.54 & \\
\multirow{2}{*}{ L-Feed } & Non & $30.7 \pm 1.39^{b)}$ & 1.00 & 1.43 \\
& Anti-Thyl.2+C' & $14.5 \pm 0.99^{a)}$ & 0.47 & \\
\hline
\end{tabular}

Significance of differences ( $t$-test): a) $p<0.05, b) p<0.01$.

was potentiated about 1.9 times by the L-feed, compared with that for the same cell fraction from mice given normal feed.

MM-46 tumor-bearing $\mathrm{C} 3 \mathrm{H}$ mice were maintained on $\mathrm{L}$-feed, and spleen cells containing NK cells were obtained from the isolated spleen. The cytotoxic activity against P-815 tumor cells was assessed. The cytotoxicity in tumor-bearing mice might be due in part to lymphokine-activated killer cells (LAK), but the whole cytotoxic activity including both NK and LAK was taken as activity of NK cells in this experiment, because the separation of NK cells from the other cells was difficult. As shown in Fig. 2, in the case of tumor-bearing mice, the cytotoxicity of NK cells were clearly decreased, but after L-feed for $7 \mathrm{~d}$, the activity rose transiently to above the normal level. After that, the activity decreased, but this reduction was slower than that in mice receiving normal feed. When the tumor-bearing mice were given Lfeed for $21 \mathrm{~d}$, the cytotoxic activity of NK cell was about $71 \%$ of the level of normal mice. However, the activity was only $21 \%$ when the tumor-bearing mice were given normal feed for the same time. These results suggested that shiitake powder directly potentiates the cytotoxicity of NK cells, or accelerates the differentiation of inactive pre-NK cells to active NK cells.

Generally, T cells (Tc) show specific cytotoxicity against allogeneic cells used for immunization. According to Hamuro et al., ${ }^{9}{ }^{9} \beta$-glucans including lentinan potentiate mouse Tc induction in vivo and in vitro. Whether shiitake fruit bodies (containing lentinan) show a similar effect or not was studied. The results are given in Table VI. After sensitization by grafting P-815 tumor cells as antigen cells intraperitoneally into $\mathrm{C} 3 \mathrm{H}$ mice, mice were given $\mathrm{L}$ feed for $15 \mathrm{~d}$. Then, their spleens were extirpated, and suspensions of whole spleen cells and spleen cells containing no $\mathrm{T}$ cells were prepared. The cytotoxicity of whole spleen cell suspension was increased 1.4 times by shiitake powder, but the fractions lacking $\mathrm{T}$ cells 
showed a marked decrease. The results suggest that the cytotoxicity potentiated by oral administration of shiitake fruit bodies is that of $\mathrm{T}$ cells. That is, shiitake fruit bodies accelerate the induction of Tc cells.

In summary, the action mechanisms of orally administered fruit bodies of shiitake seem to be similar to those of lentinan injected i.p. into mice. Shiitake powder showed antitumor action against several syngeneic tumors, and acts not only by activation of various effector cells (Mø, NK cells, Tc, etc.) to attack tumor cells, but also by potentiating the cellular functions and preventing a decrease of immune functions of the tumor-bearing host.

\section{References}

1) H. Nanba, K. Mori, T. Toyomasu and H. Kuroda, Chem. Pharm. Bull., 35, 2453 (1987).

2) Y. Y. Maeda, G. Chihara and K. Ishimura, Nature (London), 52, 250 (1974).

3) J. Hamuro, H. Wagner and M. Röllinghoff, Cell Immunol., 38, 328 (1978).

4) M. Ito, H. Suzuki, N. Nakano, N. Yamashita, E. Sugiyama, M. Maruyama, K. Hoshino and S. Yano, Gann, 74, 128 (1983).

5) O. H. Lowry, N. J. Rosebrough, A. L. Farr and R. J. Randall, J. Biol. Chem., 193, 265 (1951).

6) K. Hashimoto and T. Kitagawa, Cell Antigen, IV, 352 (1972).

7) N. Saijo, A. Ozaki, Y. Beppu, N. Irimajiri, M. Shibuya, E. Shimizu, T. Takizawa, T. Taniguchi and A. Hoshi, Gann, 74, 137 (1983).

8) H. Nakajima, S. Abe, Y. Masuko, J. Tsubouchi, M. Yamazaki and D. Mizuno, Gann, 72, 723 (1981).

9) J. Hamuro, H. Wagner and M. Röllinghoff, Cell Immunol., 38, 328 (1978).

10) J. Hamuro, M. Röllinghoff and H. Wagner, Cancer Res., 38, 3080 (1978). 